Original article

Section: Nutrition Research

\title{
Tumor Anti-Initiation and Anti-Progression Properties of Sulphated-Extract of Colocasia esculenta
}

\author{
Amira M. Gamal-Eldeen ${ }^{1 *} \oplus^{\oplus}$, Hassan Amer ${ }^{2} \odot$, Cinderella A. Fahmy ${ }^{3,4} \oplus$,

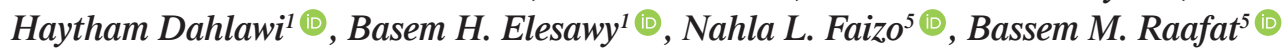 \\ ${ }^{1}$ Clinical Laboratory Sciences Department, College of Applied Medical Sciences, Taif University, \\ P.O. Box 11099, Taif 21944, Saudi Arabia \\ ${ }^{2}$ Department of Natural and Microbial Products Chemistry, National Research Centre, Dokki, Cairo 12622, Egypt \\ ${ }^{3}$ Cancer Biology and Genetics Laboratory, Centre of Excellence for Advanced Sciences, \\ National Research Centre, 33 El Buhouth St. Dokki, Cairo, 12622, Egypt \\ ${ }^{4}$ Biochemistry Department, National Research Centre, 33 El Buhouth St. Dokki, Cairo, 12622, Egypt \\ ${ }^{5}$ Radiological Sciences Department, College of Applied Medical Sciences, Taif University, \\ P.O. Box 11099, Taif 21944, Saudi Arabia
}

Key words: Colocasia esculenta, CYP1A, cancer chemoprevention \& tumor anti-initiating, HDAC, macrophage function, breast MCF-7 carcinoma

Colocasia esculenta (Taro) is an edible tuberous plant; however, corms are its most worldwide consumed part while the corm powder is widely used in food industries. In this work, a sulphated polysaccharide extract of $C$. esculenta corm (SCE) was prepared and its cancer chemopreventive properties were explored. The amending of carcinogen metabolism and radical scavenging affinity revealed that SCE is a strong tumor anti-initiation agent via suppressing cytochrome P450-1A and enhancing glutathione and the carcinogen detoxification enzyme; glutathione $S$-transferase. SCE exhibited a strong scavenging affinity towards critical radicals (hydroxyl and peroxyl). It induced lymphocyte growth and modulated the macrophage functions into an anti-inflammatory profile, via elevating macrophage proliferation and its binding affinity of fluorescein isothiocyanate-lipopolysaccharide (FITC-LPS) and inhibiting nitric oxide and tumor necrosis factor- $\alpha$ generation. Furthermore, SCE showed a potent cytotoxicity against human breast MCF-7 carcinoma cells $\left(\mathrm{IC}_{50} 27.73 \mu \mathrm{g} / \mathrm{mL}\right.$ ), whereas SCE treatment inhibited the activity of histone deacetylase (HDAC IC $\mathrm{I}_{50} 37.70 \mu \mathrm{g} / \mathrm{mL}$ ) and disturbed the pattern of cell cycle phases. An arrest in both S- and G2/M-phases was linked with shifted cell populations towards late apoptosis and necrosis, as detected by flow cytometry. SCE is a promising cancer chemopreventive agent to be used in healthy food industries and for the high breast cancer-risk population.

\section{INTRODUCTION}

Colocasia esculenta (Liliatae, Araceae), traditionally called taro, is a tuberous plant classified as monocotyledonous and distributed in humid subtropics and tropics. All of the plant parts are edible; however, corms are its most worldwide consumed part [Lim, 2015]. The corms afford various nutrients, including proteins, carbohydrates, vitamins (niacin, riboflavin, and thiamine), minerals (iron, potassium, sodium, calcium, and phosphorus) and fibers [Temesgen \& Retta, 2015]. Additionally, many bioactive compounds were extracted from C. esculenta; e.g., phenolic compounds (including anthocyanins and tannins), sterols, organic acids, bioactive proteins, phytocystatin, alkaloids, terpenes, and saponins [Ferreres et al., 2012; Lim, 2015; Reyad-ul-Ferdous et al., 2015]. Preclinical studies reported that $C$. esculenta corm extracts exerted antitumoral and antimetastatic [Kundu et al., 2012; Park et al., 2013], antihyperlipidemic [Sakano et al., 2005], antioxidant [Lee et al., 2011], wound healing [Gonçalves et al., 2013], antidiabetic [Eleazu et al., 2013], and antiviral [Keyaerts et al., 2007] properties.

The widespread traditional usages of $C$. esculenta are for many health disorders including: gastrointestinal diseases, diabetes mellitus, alopecia, internal hemorrhages, anemia, body ache, snakebite, and additionally for immune system stimulation [Lim, 2015, Nwauzoma \& Dappa, 2013]. C. esculenta corm powder is marketed as an ingredient and as a food supplement, worldwide. The flour constituents of $C$. esculenta are comparable to corn, potato, and soybean ones; it has a high fiber a low fat content, which makes the flour a satisfactory substitute for market flours as an economic alternative in developing countries [reviewed in Pereira et al., 2018]. С. еsculenta flour may be utilized in numerous preparations, such as bread, noodle, cookies, paste, and infant formulations,

\footnotetext{
* Corresponding Author:

E-mail: amabdulaziz@tu.edu.sa, aeldeen7@yahoo.com. (A.M. Gamal-Eldeen)
} 
especially for dietary restriction cases (e.g., gluten intolerance and allergenic disorders) [Kaushal et al., 2015; Noorfarahzilah et al., 2014].

The defensive mechanisms that provide prevention of the carcinogenesis cascade are defined as chemoprevention perception. Chemopreventive agents are capable to prevent, reverse or postpone carcinogenesis cascade. Daily consumption of these agents represents a hopeful approach to suppress or prevent carcinogenesis [Mollakhalili et al., 2017]. A variety of phytochemicals originated from dietary plants are proved to hinder specific carcinogenesis stages through the inhibition of tumor initiation, promotion, and progression, which among others, encompassed the modulation of the cancer cell cycle, proliferation inhibition, and initiation of apoptosis [Mollakhalili et al., 2017].

In our previous studies, we reported that the sulphated forms of natural polysaccharides showed promising tumor cancer chemopreventive potentials [Gamal-Eldeen et al., 2006; 2007a,b 2009; 2021]. In continuation, the current study was planned to explore the cancer chemopreventive mechanisms of a sulphated extract of $C$. esculenta corms, targeting to function as a cancer chemopreventive alternative in the healthy food industries for high-risk populations.

\section{MATERIAL AND METHODS}

\section{Preparation of the sulphated $\boldsymbol{C}$. esculenta extract}

C. esculenta tubers $(2 \mathrm{~kg})$ were purchased from the local market (Dokki, Giza). Corms were washed and cleaned from the foreign substances, peeled, and chopped into smaller pieces $\left(\sim 1 \mathrm{~cm}^{3}\right)$. Afterward, the pieces were macerated with distilled water in a kitchen blender, and then extracted for $1 \mathrm{~h}$ with hot water under reflux. A filtration was carried out to discard insoluble material, and the filtrate was dialyzed for $48 \mathrm{~h}$ against running distilled water, prior overnight incubation with cold ethanol $(1: 4 ; v / v)$. The precipitate was gathered by centrifugation before vacuum drying (crude polysaccharides). Sulphated $C$. esculenta extract (SCE) was prepared rendering to published methods [Mähner et al., 2001; Yang et al., 2003]. In brief, the sulphating agent was developed by dropping $20 \mathrm{~mL}$ of fuming sulphuric acid into $100 \mathrm{~mL}$ of formamide, in a cooling chamber. The crude polysaccharides $(4 \mathrm{~g}$ ) were mixed with formamide and then mixed with the sulphation solution $(120 \mathrm{~mL})$ under overnight stirring. After cooling, consecutive steps were carried out including neutralization by $1 \mathrm{~N} \mathrm{NaOH}$, dialysis against distilled water for $48 \mathrm{~h}$, and finally lyophilization. All of the chemicals were purchased from Sigma-Aldrich (Saint Louis, MO, USA), unless otherwise mentioned.

\section{Characterization of the sulphated $\boldsymbol{C}$. esculenta extract}

The total carbohydrate content of SCE was estimated by the phenol- $\mathrm{H}_{2} \mathrm{SO}_{4}$ protocol [DuBois et al., 1956]. The total protein was determined with the Lowry method [Lowry et al., 1951]. The sugar composition was estimated after a complete hydrolysis of polysaccharides with $\mathrm{H}_{2} \mathrm{SO}_{4}(2 \mathrm{M})$ at $100^{\circ} \mathrm{C}$ for $8 \mathrm{~h}$. The hydrolysate was neutralized by $\mathrm{BaCO}_{3}$ and then Dowex 50 resin $\left(\mathrm{H}^{+}\right.$form) was used. The chromatography for $24 \mathrm{~h}$ on Whatmann no. 1 paper with butanol: acetone: water
(4:5:1, v/v/v) as a mobile phase was applied to separate the individual sugars [Partridge et al., 1949]. The spots were sprayed with aniline phthalate for visualization. The total sulphate content was determined after hydrolysis with $\mathrm{HCl}$ [Larsen et al., 1966] and the liberated sulphate ions were estimated by $\mathrm{BaCl}_{2}$ turbidimetric method [Hunt, 1980].

\section{Cell culture}

Various cell lines were utilized through the study, including human breast carcinoma (MCF-7), human hepatocellular carcinoma (Hep G2), human lymphoblastic leukemia (1301) and raw murine macrophages (RAW 264.7); purchased from the American Type Culture Collections (ATCC, Manassas, VA, USA). RAW 264.7 cells were cultured in Roswell Park Memorial Institute Medium-1640 (RPMI-1640), while the other cell lines were routinely cultured in Dulbecco's Modified Eagle Medium (DMEM). Media were supplemented with 10\% fetal bovine serum (FBS), $2 \mathrm{mM}$ L-glutamine, $100 \mathrm{U} / \mathrm{mL}$ streptomycin sulfate, $100 \mathrm{U} / \mathrm{mL}$ penicillin $\mathrm{G}$ sodium, and $250 \mathrm{ng} / \mathrm{mL}$ amphotericin B. Cells were maintained in humidified air containing $5 \% \mathrm{CO}_{2}$ at $37^{\circ} \mathrm{C}$. Extracts were dissolved in the cell matching medium. The extract stocks were examined, before assay dilutions, for endotoxins by the Pyrogent ${ }^{\circledR}$ Ultra gel clot assay to confirm endotoxin-free status. Materials for cell culture were purchased from Lonza (Morristown, NJ, USA). All of the cellular experiments were repeated $(n=8)$, except flow cytometry analysis $(n=4)$.

\section{Tumor anti-initiation activity}

The total cellular capacity for scavenging the physiologically dangerous radicals; peroxyl (ROO*) and hydroxyl $\left(\mathrm{OH}^{\bullet}\right)$; was investigated by the oxygen radical absorbance capacity (ORAC) assay, which is an indication of the total antioxidant activity of the cells [Cao \& Prior, 1999; Gamal-Eldeen et al., 2004]. Hep-G2 cells were treated with $10 \mu \mathrm{g} / \mathrm{mL}$ of SCE for $24 \mathrm{~h}$. The protein content of the cell lysate was measured and only $1 \mu \mathrm{g}$ protein/mL was subjected to ORAC assay. $\beta$-Naphthoflavone-treated Hep-G2 cells were used as cytochrome P450 1A1 (CYP1A1) source, which was further treated with SCE $(1 \mu \mathrm{g} / \mathrm{mL})$, and then CYP1A1 was assessed by the dealkylation rate of 3-cyano-7-ethoxycoumarin into 3-cyano-7-hydroxycoumarin [Crespi et al., 1997; Gerhäuser, et al., 2003]. Glutathione $S$-transferase (GST) activity was estimated in $1 \times 10^{6}$ Hep G2 cells after being incubated with SCE (10 and $20 \mu \mathrm{g} / \mathrm{mL}$ ) for $48 \mathrm{~h}$ [Habig et al., 1974]. The kinetic analysis was traced at $340 \mathrm{~nm}$, and then GST concentration was normalized to the protein content. The total thiol content was estimated by an enzymatic method [Griffith, 1980].

\section{Tumor anti-promoting activity and macrophage functions}

To select a safe dose, the macrophage proliferation index was calculated for RAW 264.7 cells $\left(0.5 \times 10^{5}\right.$ cells/well $)$ after being seeded with SCE $(0-40 \mu \mathrm{g} / \mathrm{mL})$ for $48 \mathrm{~h}$. Cell viability was assessed by MTT test. RAW 264.7 cells were cultured in phenol red-free RPMI, to estimate both of the secreted tumor necrosis factor- $\alpha$ (TNF- $\alpha$ ) by ELISA kit (R\&D Systems, Minneapolis, $\mathrm{MN}$ ) and the generated nitric oxide (NO), as assayed by Griess reagent in Moorcroft et al. [2001]. Macrophages were treated with bacterial lipopolysaccharide 
(LPS, $1 \mu \mathrm{g} / \mathrm{mL})$ for $24 \mathrm{~h}$ and with/without SCE $(10 \mu \mathrm{g} / \mathrm{mL}$ and $20 \mu \mathrm{g} / \mathrm{mL}$ ). Additionally, the SCE influence on the binding affinity of FITC-conjugated LPS to macrophages was evaluated [Carracedo et al., 2002]. Cells were seeded with SCE (10 and $20 \mu \mathrm{g} / \mathrm{mL})$ in phenol red-free RPMI with $10 \%$ FBS (source of CD14 and LPS-binding protein), then incubated for $1 \mathrm{~h}$, and the FITC-LPS binding affinity was detected via microplate fluorometer (FluoStarOptima, BMG, USA).

\section{Tumor anti-progression effect}

Cytotoxicity of SCE against human cancer cells was evaluated by the 3-[4,5-dimethyl-2-thiazolyl)-2,5-diphenyl-2H-tetrazolium bromide (MTT) assay after $48 \mathrm{~h}$ after the treatment of $0.5 \times 10^{5}$ cells/well with SCE $(0-40 \mu \mathrm{g} / \mathrm{mL})$ for $48 \mathrm{~h}$. Thereafter, the media were discarded and $40 \mu \mathrm{L}$ MTT solution/well were added and incubated for $4 \mathrm{~h}$. MTT crystals were solubilized by acidified isopropanol [Hansen, et al., 1989]. Photometric readings were recorded at $570 \mathrm{~nm}$ using a microplate ELISA reader. The analysis of cell cycle phases in $5 \times 10^{5} \mathrm{MCF}-7$ cells $/ \mathrm{mL}$ after being treated with $\mathrm{SCE}\left(\mathrm{IC}_{50}\right)$ for $12 \mathrm{~h}$ was carried out by flow cytometry after cell staining with propidium iodide (PI), using a flow cytometer (Becton Dickinson, San Jose, CA, USA). The PI/FITC-anti-Annexin V Kit (Invitrogen, Waltham, MA, USA) was used to estimate apoptosis/necrosis by flow cytometry. MCF-7 cells were treated with SCE $(0-40 \mu \mathrm{g} / \mathrm{mL})$ for $48 \mathrm{~h}$, and then the activity of histone deacetylase (HDAC) was measured in the cell lysate by a colorimetric kit (BioVision, Milpitas, CA, USA) according to the manufacturer's instructions.

\section{Data analysis}

Data were statistically analyzed by Student's unpaired t-test and one-way ANOVA test. The differences between mean values were considered insignificant at $p>0.05$.

\section{RESULTS AND DISCUSSION}

Halting, suppressing, retarding or reversing the sequence of carcinogenesis stages is regularly called "cancer chemoprevention", which is mostly achieved via using natural semi-natural, or synthetic chemicals to neutralize carcinogens [Tan et al., 2011]. Plant extracts are known to possess widerange mechanistic chemopreventive activity, through blocking the enzymatic carcinogen-activation process in tumor initiation stage or inhibiting the growth of the pre-neoplastic and neoplastic cells [Tan et al., 2011]. The current study is an attempt to recognize whether SCE acts as a blocking or a suppressing agent.

\section{Characterization of sulphated $\boldsymbol{C}$. esculenta extract}

The analysis of the chemical composition of SCE revealed that after the sulphation process, the sulphate substitution in SCE was $48 \%$ with a sulphation degree of 2.3 (molar ratio to monosaccharide unit) (Table 1) that indicated the accomplishment of the sulphation reaction. Chromatography analysis of SCE acid hydrolysates revealed the occurrence of a significant amount of glucose, and smaller amounts of mannose, galactose and uronic acids, as well as traces of arabinose, xylose, and rhamnose (Table 1 ).

\section{Tumor anti-initiation activity}

In oxidative stress status and inflammatory condition, extreme generation of reactive oxygen (ROS) and nitrogen (RNS) species occurs and causes DNA damage that ignites tumor initiation and promotion cascade [Sun et al., 2004]. Accordingly, eliminating the excess of physiologically-pertinent ROS, such as $\mathrm{ROO}^{\circ}$ and $\mathrm{OH}^{*}$, affords an effective approach to halt tumor initiation and promotion. Likewise, the augmentation of the non-enzymatic antioxidants; total thiols, supports the attenuation of ROS harmful effect. The total cell lysate capacity for scavenging the radicals; $\mathrm{OH}^{*}$ and $\mathrm{ROO}^{*}$; was assessed by ORAC assay in HepG2 cells. The results indicated that SCE remarkably enhanced the total cellular capacity to scavenge both radicals (Figure 1a). However, the affinity to scavenge $\mathrm{OH}^{*}$ was higher than $\mathrm{ROO}^{*}$, as concluded from their ORAC units in comparison with Trolox, where one ORAC unit is equivalent to the protection of the fluorescence decay of $\alpha$-phycoerythrin ( $\alpha$-PE) achieved by Trolox $(1.0 \mu \mathrm{M})$.

To antagonize xenobiotics and toxic agents, cells emerged a panel of responding genetic amendments that help them to repress the damaging effect of toxicants. Those amendments include upregulation of drug-metabolizing enzymes, cytoprotective proteins, and drug transporters, that facilitate clearance of toxicants from the body and restore normal homeostasis. Nuclear factor-erythroid 2-related factor 2 (Nrf2) as well as aryl hydrocarbon receptor (AhR) are transcription factors that mediate the enzymatic response towards xenobiotics [Hayes et al., 2009]. Among others, transcription factor AhR regulates CYP1A1 expression, which is triggered by its conjugation with polycyclic aromatic hydrocarbons. The metabolizing of exogenous and endogenous substrates is regulated by monooxygenase, which is primarily encoded by CYP1A1 gene. CYP1A1 is a pivotal player in the metabolism of benzo[ $\alpha]$ pirene and linked polycyclic aromatic hydrocarbons, transferring both into strongly dangerous carcinogens. Accordingly, the enhanced expression of CYP1A1

TABLE 1. Chemical composition of a sulphated water-soluble extract of $C$. esculenta (SCE).

\begin{tabular}{lc}
\hline Chemical composition & Value \\
\hline Carbohydrate $(\mathrm{g} / 100 \mathrm{~g})$ & 35.4 \\
Protein $(\mathrm{g} / 100 \mathrm{~g})$ & 0.8 \\
Sulphate $(\mathrm{g} / 100 \mathrm{~g})$ & 48.0 \\
Degree of sulphation & 2.3 \\
\hline Relative monosaccharide contents $(\mathrm{g} / 100 \mathrm{~g})$ & \\
\hline Uronic acid & 1.15 \\
Galactose & 4.0 \\
Glucose & 83.5 \\
Mannose & 11.0 \\
Arabinose & Traces \\
Xylose & Traces \\
Rhamnose & Traces \\
\hline
\end{tabular}


a)

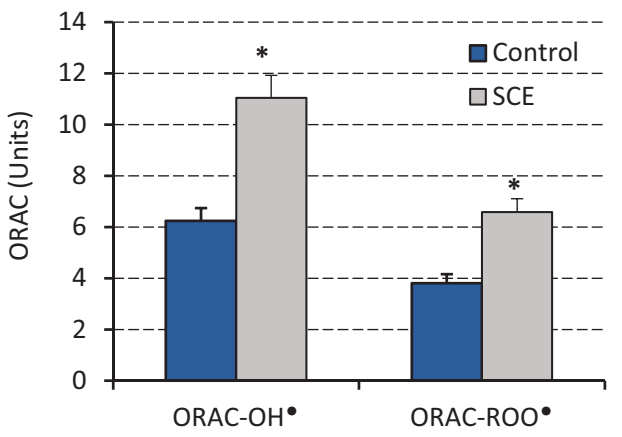

b)

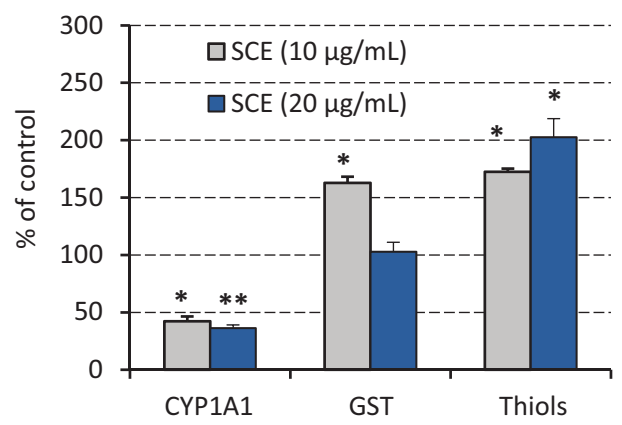

FIGURE 1. Tumor anti-initiating activity: (a) Oxygen radical absorbance capacity (ORAC) was used to investigate the radical scavenging (antioxidant) activity against $\mathrm{OH}^{*}$ and $\mathrm{ROO}{ }^{*}$ in Hep-G2 cell lysate after being treated with a sulphated $C$. esculenta extract (SCE) in comparison with control cells. Data are expressed in ORAC units. (b) The modulation of the carcinogen metabolism: The effect of SCE (10 and $20 \mu \mathrm{g} / \mathrm{mL})$ on the purified cytochrome P450 1A1 (CYP1A1; $1 \mu \mathrm{g}$ protein/mL) and the cellular levels of glutathione $S$-transferase (GST) and total thiol content in Hep-G2 cells was investigated. Data was expressed as mean percentage \pm standard error and control represents $100 \%$ of the scale. In control cells, GST and total thiol contents were $118 \mathrm{nmol} / \mathrm{min} / \mathrm{mg}$ protein and $84 \mathrm{nmol} / \mathrm{min} / \mathrm{mg}$ protein, respectively. * $p<0.05$ and ${ }^{* *} p<0.01$.

gene is an indicator for AHR stimulation and is associated with the metabolism and toxicity of xenobiotics [Mescher \& Haarmann-Stemmann, 2018]. Therefore, CYP1A1 is considered as a potential molecular target to modulate and prevent chemically-induced carcinogenesis.

Alteration of different enzymes that participate in the metabolic activation of carcinogens (phase I enzymes) and in the detoxification of carcinogens (phase II enzymes), is an effective strategy for recognizing cancer anti-tumor initiation agents. The estimation of the inhibitory effect of SCE on CYP1A1 enzyme, as one of the phase I-enzymes participating in the transformation of procarcinogens into active carcinogens, revealed that SCE $(10 \mu \mathrm{g} / \mathrm{mL}$ and $20 \mu \mathrm{g} / \mathrm{mL})$ can be recognized as a strong inhibitor of CYP1A1 activity $(p<0.01)$ with inhibition of $57 \%$ and $64 \%$, respectively (Figure 1b), in comparison to control.

In carcinogenesis, the initiation is the very early and crucial event, where it functionally promotes the clonal cell growth under the control of promoters and ends eventually with consequent preneoplastic cell generations [Bertram, 2000]. Retarding or stopping the initiation stage through suppressing the activators of carcinogen metabolism (e.g., CYP1A), enhancing the carcinogen detoxification (e.g., glutathione (GSH) and GSTs), and increasing cellular antioxidant activity are efficient operative strategies. A fundamental indicator of the cellular defense against the oxidative stress is the total thiol level, especially GSH, the key cytosolic thiol, that supports the elimination of peroxides and other free radicals [Aggarwal \& Shishodia, 2006]. GSH homeostasis depends on its binding to GSTs, which is a panel of enzymes that regulates xenobiotic detoxification and defends the cells against carcinogens. GSTs generally amend the cellular GSH levels according to the ROS generation level [Prabhu \& Guruvayoorappan, 2010]. In Hep-G2 cells, GST was explored (as one of phase II enzymes) after $48 \mathrm{~h}$ of cell seeding with $\operatorname{SCE}(10 \mu \mathrm{g} / \mathrm{mL})$. Its activity was elevated up to $162.47 \%$ of the control $(p<0.05)$, as shown in Figure 1b, while it remained unaffected by the higher SCE. The assessment of the total thiol level indicated that SCE dramatically increased the thiol content in cells in both of the tested doses (Figure 1b).

Our results revealed that SCE is an effective tumor anti-initiating agent, since it dramatically suppressed CYP1A activity. Cellular antioxidants guard the cells from the harm of dangerous physiological radicals, such as hydroxyl and peroxyl radicals, that can attack critical protein and DNA molecules. The cellular antioxidants maintain the homeostatic balance of cellular ROS [Bertram, 2000], whenever this balance is impaired, it directly disturbs cellular growth, apoptosis, and senescence. Our findings indicated that SCE strongly increased the total cellular scavenging activity, as estimated in the cell lysate of SCE-treated Hep-G2 cells, against $\mathrm{OH}^{\bullet}$ and ROO•, with higher affinity towards $\mathrm{OH}^{\bullet}$, compared with the scavenging activity of cell lysate of untreated cells.

\section{Tumor anti-promoting activity and modulation of macrophage function}

As a key player in innate and adaptive immune responses, macrophages are regularly engulfing and then digesting pathogens via discharging mediators of inflammation including NO that is a potential RNS that in turn transforms into many oxidation products which are capable to trigger the carcinogenesis initiation and promotion [Prabhu \& Guruvayoorappan, 2010]. The strong affinity of SCE to scavenge variable radicals including its suppressing of the LPS-induced NO may indicate that the suppression was because of a direct NO scavenging or via inhibiting iNOS pathway. The macrophage growth induced after SCE treatment may be associated with an elevation in the expression of the macrophage growth factor; IL-12. The outer membrane of Gram-negative bacteria enclosed LPS that is an essential molecule in septic shock pathogenesis.

LPS regularly conjugates the serum acute-phase reactant LPS-binding protein (LBP) that transports LPS to CD14 (a primary LPS receptor in serum) and as a glycophosphatidylinositol-linked agent on mononuclear phagocytes surface. LPS-CD14 activates the generation of the inflammatory cytokines [Kitchens, 2000]. Subsequently, the effective 
a)

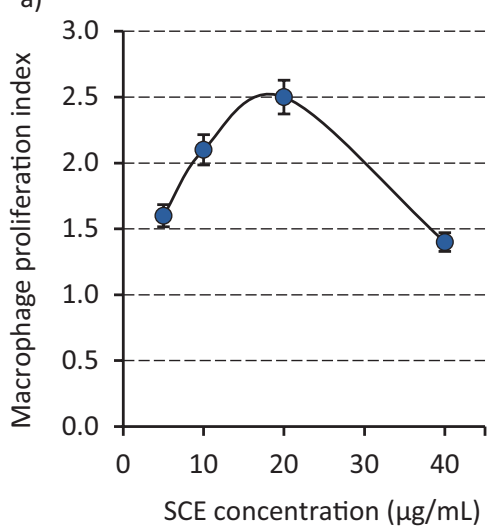

c)

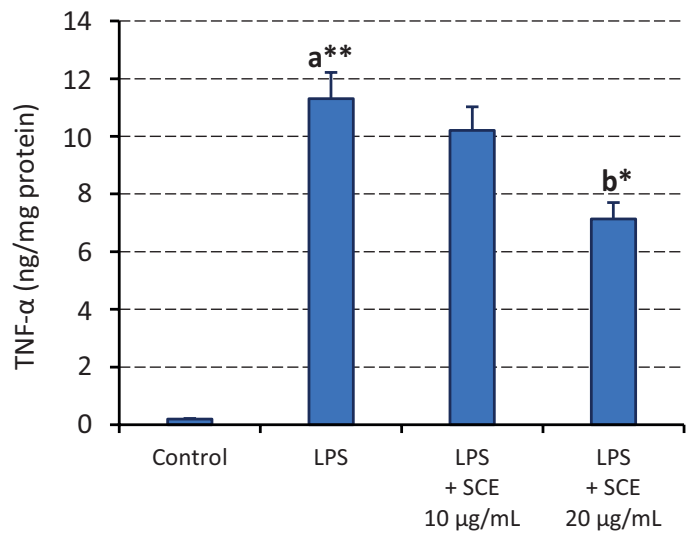

b)

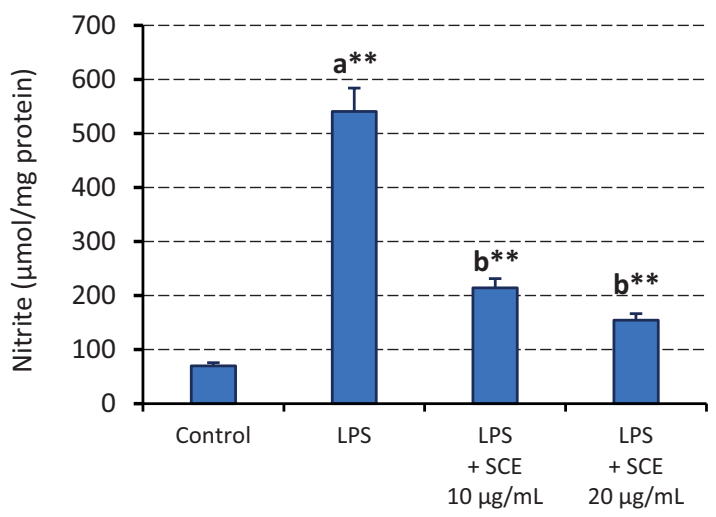

d)

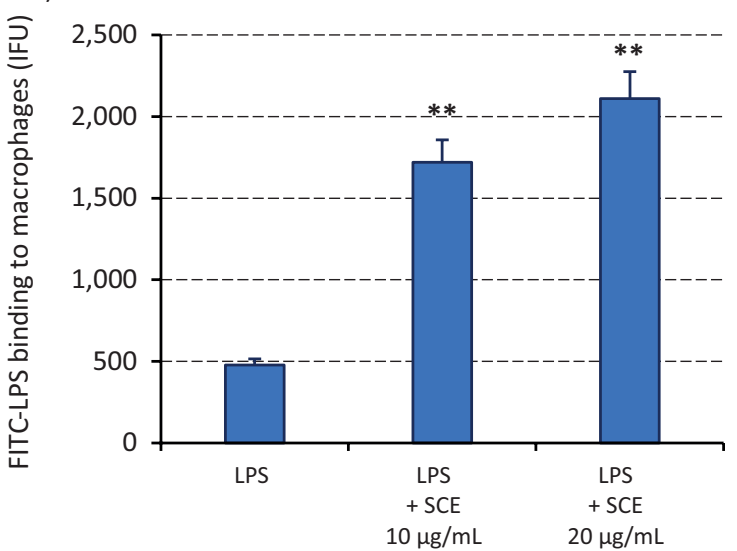

FIGURE 2. Modulation of macrophage function: (a) Macrophage proliferation index (folds of control) in sulphated C. esculenta extract (SCE) treated Raw 264.7 cells. (b) Nitric oxide (NO) production ( $\mu \mathrm{mol} / \mathrm{mg}$ protein). (c) Tumor necrosis factor (TNF- $\alpha$ ) concentration (ng/mg protein) were estimated in the supernatants of Raw 264.7 after being stimulated by bacterial lipopolysaccharide (LPS) before being treated with/without 10 \& $20 \mu \mathrm{g} / \mathrm{mL}$ SCE. (d) Analysis of fluorescein isothiocyanate-LPS (FITC-LPS) binding affinity to Raw 264.7 cells by flow cytometry. Data was expressed as mean

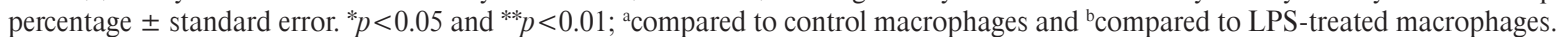

enhancement of the macrophages/LPS binding affinity by SCE may ultimately result in enhanced LPS-LBP conjugation and/or LPS-CD14 conjugation. C. esculenta extract treatment for Her-2/neu negative murine mammary tumor cell line (410.4) showed antimetastatic activity, which suggested to be due to its inhibition of the inflammatory mediators including the suppression of prostaglandin $\mathrm{E}_{2}\left(\mathrm{PGE}_{2}\right)$ synthesis and downregulation of cyclooxygenase (COX) 1 and 2 expressions [Kundu et al., 2012].

The influence of SCE on the macrophage proliferation and its functionality was explored. The results demonstrated that SCE displayed a gradual dose-dependent immunoproliferative outcome on macrophages (Figure 2a) to the highest level of 2.51 -fold of control at $20 \mu \mathrm{g} / \mathrm{mL}(p<0.05)$, but not in the highest dose used. This high macrophage proliferation led to the interest of further investigations to check if this proliferation was concurrently accompanied with elevated macrophage functions. Bacterial LPS was used to induce inflammation cascade in the RAW 264.7 cells before being further treated with SCE. Interestingly, treating RAW 264.7 cells with SCE $(10 \mu \mathrm{g} / \mathrm{mL}$ and $20 \mu \mathrm{g} / \mathrm{mL})$ resulted in a significant inhibition $(p<0.01)$ in the LPS-stimulated NO production, where it inhibited $60.32 \%$ and $71.43 \%$ of the LPS-generated NO, respectively (Figure 2b). While only the dose of $20 \mu \mathrm{g} / \mathrm{mL}$ of SCE significantly inhibited $(p<0.05)$ the TNF- $\alpha$ release from LPS-treated macrophages (Figure 2c). The affinity of macrophages to bind a tumor surface antigen or a pathogen is their essential mechanistic activation function. That binding was traced after the seeding of macrophages with FITC-LPS with/without SCE $(10 \mu \mathrm{g} / \mathrm{mL}$ and $20 \mu \mathrm{g} / \mathrm{mL})$. The results revealed that both doses of SCE dramatically suppressed $(p<0.01)$ the macrophage binding affinity to FITC-LPS (Figure 2d).

\section{Anti-progression activity}

Exploring the cytotoxicity of SCE against solid tumor cell lines showed a remarkable dose-dependent cytotoxicity in breast MCF-7 cells $\left(\mathrm{IC}_{50} 27.73 \mu \mathrm{g} / \mathrm{mL}\right)$ and a lower cytotoxicity extent in the case of Hep-G2 cells $\left(\mathrm{IC}_{50} 64.32 \mu \mathrm{g} / \mathrm{mL}\right)$, as shown in Figure $3 \mathrm{a}$. However, the treatment of the hematopoietic tumor cells (1301 leukemia) with SCE resulted in a gradual increment in the lymphocyte proliferation, up to 1.5 -fold at $40 \mu \mathrm{g} / \mathrm{mL}$ (Figure $3 \mathrm{a}$ ).

Consequently, the effect of SCE on MCF-7 cell cycle phases was investigated, whereas the untreated MCF-7 cells exhibited an intact pattern of cell cycle stages, as 96.3\% of the cell's population appeared in G0/G1 phase (Figure 3b). SCE treatment resulted in a significant arrest 
a)

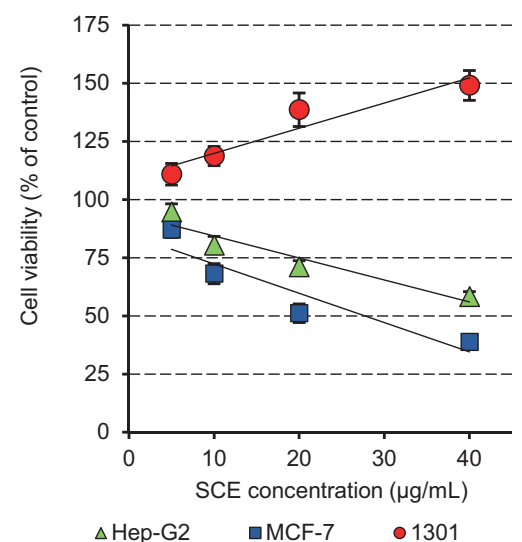

b)

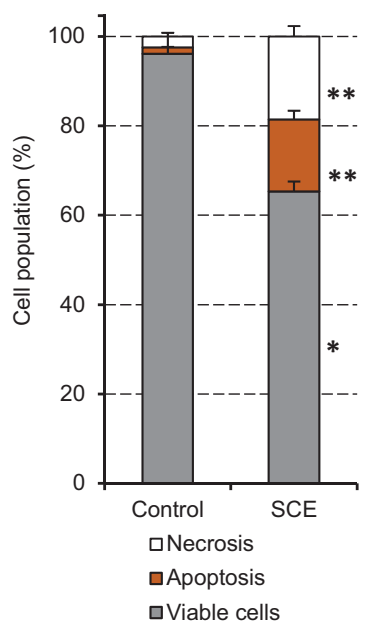

c)

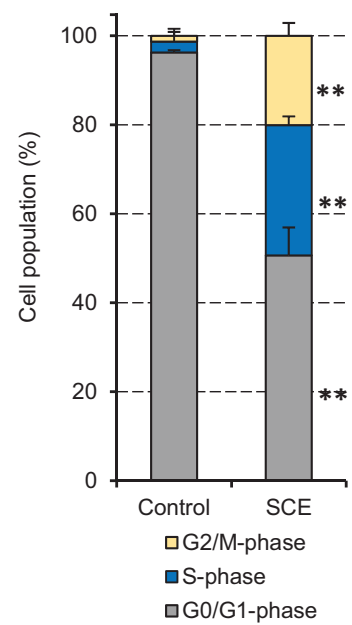

d)

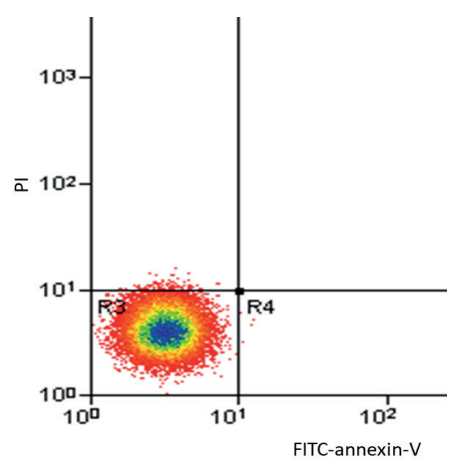

e)

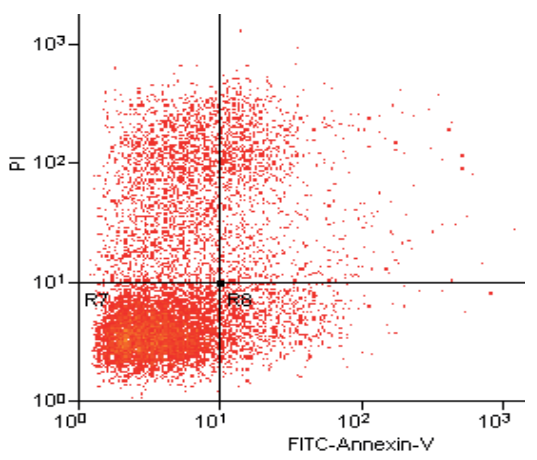

f)

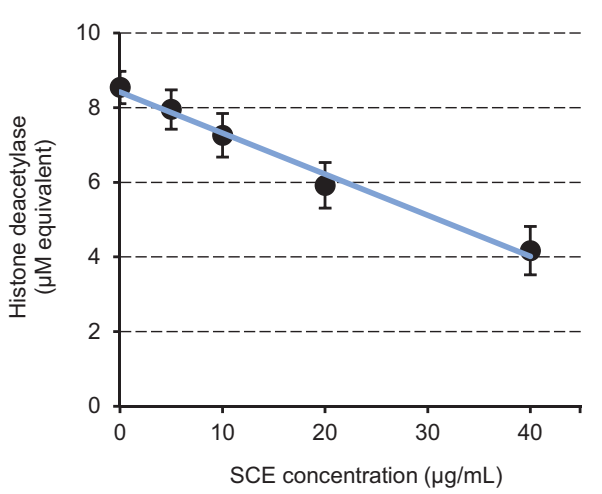

FIGURE 3. Anti-progression activity: (a) Cytotoxicity of a sulphated C. esculenta extract (SCE) against different human cancer cell lines. (b) Cell cycle analysis of breast MCF-7 cells after being treated with SCE $\left(20 \% \mathrm{IC}_{50} ; 48 \mathrm{~h}\right)$, compared with control cells. (c-e) The analysis of apoptosis and necrosis (by anti-annexin V-FITC/PI) in MCF-7 cells that were seeded without/with $20 \% \mathrm{IC}_{50}$ of SCE for $12 \mathrm{~h}$. The data are presented as percentages of the cell population, while in (e) the flow cytometry dot plots for the cells are presented. (f) Histone deacetylase (HDAC) inhibition in SCE-treated MCF-7 cells. Data were presented as mean percentage \pm standard error. ${ }^{*} p<0.05$ and ${ }^{* *} p<0.01$.

$(p<0.01)$ in S-phase $(29.2 \%)$, and $\mathrm{G} 2 / \mathrm{M}$ phase $(20.1 \%)$ and subsequently a concomitant significant decrease in cell population in G0/G1 phase, as shown in Figure 3b. Due to the noticed disturbance in cell cycle phases and SCE-induced cytotoxicity in MCF-7 cells, the meanwhile cell death mode stimulated by SCE was analyzed. The findings indicated that SCE encourages necrosis as much as apoptosis (Figure $3 \mathrm{c}$, Figure $3 \mathrm{e}$ ), as concluded from their total population percentages $(18.5 \%$, and $16.1 \%$, respectively), compared to the control pattern (Figure 3c, Figure 3d).

Our results indicate the cytotoxicity of SCE against breast carcinoma MCF-7 cells and hepatocellular Hep-G2 carcinoma but not with lymphoblastic leukemia, signifying the SCE specificity to solid tumor cells. Rendering the polysaccharides high molecular weight, SCE IC I0 $_{5}$ of MCF-7 cells $(27.73 \mu \mathrm{g} / \mathrm{mL})$ provides a dramatic low molar concentration of SCE. In a parallel previous report, $C$. esculenta extract was reported to similarly reduce the proliferation of some breast as well as prostate cancer cell lines [Kundu et al., 2012]. Rounded cells with morphologic alterations were recorded, where cell migration was totally jammed by taro extract [Kundu et al., 2012]. Cell death may occur due to different death mechanisms, among them are the necrosis and apoptosis that are characterized by variable morphological and biochemical events, including cell swelling, disruption, and rapid cell membrane fragmentation in necrosis and elegant nuclear and cytoplasmic disintegration and formation of apoptotic bodies [Xu et al., 2019].

In the current study, SCE induced both necrosis and apoptosis in MCF-7 cells that was activated by a parallel disorder in cell cycle phases; arrested cell population in S- and G2/M phases. The rate of cell growth can interfere in the carcinogenesis stages by multiple mechanisms; among them the cell population per se may be carcinogenic through fixing of miscoding lesion in the freshly synthesized DNA [Lund, 2011]. Cells retort to cytotoxic stress and DNA impairment by arresting cell-cycle phases, repairing DNA or enduring apoptotic cell death. A wide array of cancer chemopreventive agents displayed their antitumor activity in association with disturbing cell cycle and arrested growth, with apoptosis [Tanaka \& Ishigamori, 2011]. Subsequently, the ability of SCE to inhibit S-phase in breast cell cycle may diminish the frequency of DNA miscoding lesions. Anticancer therapeutics eliminate 
cancer cells by targeted mechanisms including damaging cell membrane, interactions with DNA, suppressing DNA replication, and attacking cells by free radicals.

Since HDAC is one of the apoptosis-regulating factors, the acetylation of histone was estimated in the MCF-7 cell lysate after being treated with different concentrations of SCE. The results revealed that SCE is a potent inhibitor of HDAC, in dose-dependent linear profile, whereas the half maximal inhibitory concentration of SCE to HDAC (HDAC $\mathrm{IC}_{50}$ ) was $37.7 \mu \mathrm{g} / \mathrm{mL}$ (Figure $3 \mathrm{f}$ ). In the current study, the apoptosis was associated with a remarkable inhibition in HDAC $\left(\mathrm{IC}_{50} 37.7 \mu \mathrm{g} / \mathrm{mL}\right)$. It is known that the post-translational histone modification "histone acetylation" is regulated by histone acetyltransferases and HDACs. By eliminating the acetyl groups, HDACs opposite the acetylation of chromatin and amend tumor suppressor genes and oncogenes transcriptions [Li \& Seto, 2016]. Interestingly, HDACs deacetylate other non-histone substrates that regulate a battery of biological pathways such as tumor initiation and progression. The therapeutic approach of HDAC inhibitors (HDACi) is an emerging cancer treatment [Li \& Seto, 2016]. Via hyperacetylation of histone/non-histone, HDACi permit the restoration of cellular acetylation homeostasis and re-establish the normal expression of proteins and inverse the processes of tumor initiation and progression [Li \&d Seto, 2016]. Accordingly, the strong inhibitory activity of SCE for HDAC is one of the mechanisms of SCE as a potential tumor anti-initiating agent.

\section{CONCLUSION}

Recently, due to their flexibility, cost-effectiveness, and desirable drug release and regulatory acceptance, many biotechnological approaches have been focused on hydrophilic polymers in pharmaceuticals. The current study findings propose SCE as a promising candidate for food industries as a functional and healthy food supplement and as an alternative of CE itself, to offer a cancer chemopreventive properties and evoke anti-inflammatory activity in targeted breast cancer-high risk communities. This study is an innovative trial to prepare a sulphated water extract of $C$. esculenta. Taken together, SCE is a strong tumor anti-initiation agent via suppressing cytochrome P450$1 \mathrm{~A}$ and enhancing the total thiol content and the carcinogen detoxification enzyme (GST). SCE exhibited a strong scavenging affinity towards critical radicals $\left(\mathrm{OH}^{*}\right.$ and $\left.\mathrm{ROO}{ }^{*}\right)$. Also, it induced lymphocyte growth and modulated the macrophage functions into an anti-inflammatory profile, via elevating macrophage proliferation, its binding affinity of FITC-LPS and, to different extent, its inhibition of $\mathrm{NO}$ and TNF- $\alpha$ generation. Furthermore, it showed a potent cytotoxicity against MCF-7 cells, disturbed cell cycle phases (S- and G2/M-phases), and enhanced late apoptosis and necrosis. SCE is a promising cancer chemopreventive agent to be used in healthy food industries and for the high breast cancer-risk population, an assumption that needs to be validated in forthcoming in vivo studies.

\section{ACKNOWLEDGEMENT}

The authors gratefully acknowledge the support of the Deanship of Scientific Research, Taif University.

\section{RESEARCH FUNDING}

This work was supported by Taif University Researchers Supporting Project Number (TURSP- 2020/103).

\section{CONFLICT OF INTEREST}

We declare that there is no conflict of interest.

\section{ORCID IDs}

H. Amer https://orcid.org/0000-0002-9595-110

H. Dahlawi https://orcid.org/0000-0002-4406-4554

B.H. Elesawy https://orcid.org/0000-0002-2581-265X

C.A. Fahmy https://orcid.org/0000-0002-2629-2473

N.L. Faizo https://orcid.org/0000-0003-4451-7602

A.M. Gamal-Eldeen https://orcid.org/0000-0002-4423-5616

B.M. Raafat https://orcid.org/0000-0003-4612-8811

\section{REFERENCES}

1. Aggarwal, B.B., Shishodia, S. (2006). Molecular targets of dietary agents for prevention and therapy of cancer. Biochemical Pharmacology, 71(10),1397-1421.

https://doi.org/10.1016/j.bcp.2006.02.009

2. Bertram, J.S. (2000). The molecular biology of cancer. Molecular Aspects of Medicine, 21(6), 167-223.

https://doi.org/10.1016/S0098-2997(00)00007-8

3. Bose, D.S., Sudharshan, M., Chavhan, S.W. (2005). New protocol for Biginelli reaction - a practical synthesis of monastrol. Arkivoc, iii, 228-236.

4. Cao, G., Prior, R.L. (1999). Measurement of oxygen radical absorbance capacity in biological samples. Methods in Enzymology, 299, 50-62.

https://doi.org/10.1016/s0076-6879(99)99008-0

5. Carracedo, J., Ramirez, R., Martin-Malo, A., Rodriguez, M., Aljama, P. (2002). The effect of LPS, uraemia, and haemodialysis membrane exposure on CD14 expression in mononuclear cells and its relation to apoptosis. Nephrology Dialysis Transplantation, 17(3), 428-434.

https://doi.org/10.1093/ndt/17.3.428

6. Crespi, C.L., Miller, V.P., Penman, B.W. (1997). Microtiter plate assays for inhibition of human, drug-metabolizing cytochromes P450. Analytical Biochemistry, 248(1), 188-190.

https://doi.org/10.1006/abio.1997.2145

7. DuBois, M., Gilles, K.A., Hamilton, J.K., Rebers, P.A., Smith, F. (1956). Colourimetric method for determination of sugars and related substances. Analytical Chemistry, 28(3), 350-356. https://doi.org/10.1021/ac60111a017

8. Eleazu, C.O., Iroaganachi, M., Eleazu, K.C. (2013). Ameliorative potentials of cocoyam (Colocasia esculenta L). and unripe plantain (Musa paradisiaca L). on the relative tissue weights of streptozotocin-induced diabetic rats. Journal of Diabetes Research, 2013, art. no. 160964.

https://doi.org/10.1155/2013/160964

9. Ferreres, F., Gonçalves, R.F., Gil-Izquierdo, A., Valentão, P., Silva, A.M.S., Silva, J.B. (2012). Further knowledge on the phenolic profile of Colocasia esculenta (L). Schott. Journal of Agricultural and Food Chemistry, 60(28), 7005-7015.

https://doi.org/10.1021/jf301739q 
10. Gamal-Eldeen, A.M., Amer, H., Alrehaili, A.A., Saleh, A., Al Ghamdi, A, Hawsawi, N.M., Salman, A., Raafat, B. (2021). Cancer chemopreventive properties of sulfated Enterolobium cyclocarpum extract. Nutrition and Cancer, 73, 856-868. https://doi.org/10.1080/01635581.2020.1773512

11. Gamal-Eldeen, A.M., Ahmed, E.F., Abo-Zeid, M.A. (2009). In vitro cancer chemopreventive properties of polysaccharide extract from the brown alga, Sargassum latifolium. Food and Chemical Toxicology, 47(6), 1378-1384. https://doi.org/10.1016/j.fct.2009.03.016

12. Gamal-Eldeen, A.M., Amer, H., Helmy, W.A. (2006). Cancer chemopreventive and anti-inflammatory activities of chemically modified guar gum. Chemico-Biological Interactions, 161(3), 229-240. https://doi.org/10.1016/j.cbi.2006.03.010

13. Gamal-Eldeen, A.M., Amer, H., Helmy, W.A., Ragab, H.M., Talaat, R.M. (2007a). Antiproliferative and cancer-chemopreventive properties of sulfated glycosylated extract derived from Leucaena leucocephala. Indian Journal of Pharmaceutical Sciences, 69(6), 805-811.

https://doi.org/10.4103/0250-474X.39438

14. Gamal-Eldeen, A.M., Amer, H., Helmy, W.A., Talaat, R.M., Ragab, H. (2007b). Chemically-modified polysaccharide extract derived from Leucaena leucocephala alters RAW 2647 murine macrophage functions. International Immunopharmacology, 7(6), 871-878.

https://doi.org/10.1016/j.intimp.2007.02.002

15. Gamal-Eldeen, A.M., Kawashty, S., Ibrahim, L., Shabana, M., El-Negoumy, S. (2004). Evaluation of antioxidant, anti-inflammatory, and antinociceptive properties of aerial parts of Vicia sativa and its flavonoids. Journal of Natural Remedies, 4, 81-96. https://doi.org/10.18311/JNR/2004/388

16. Gerhäuser, C., Klimo, K., Heiss, E., Neumann, I., Gamal-Eldeen, A., Knauft, J., Liu, G.Y., Sitthimonchai, S., Frank, N. (2003). Mechanism-based in vitro screening of potential cancer chemopreventive agents. Mutation Research, 523-524, 163-172. https://doi.org/10.1016/s0027-5107(02)00332-9

17. Gonçalves, R.F., Silva, A.M., Silva, A.M., Valentão, P., Ferreres, F., Gil-Izquierdo, A., Silva, J.B., Santos, D., Andrade, P.B. (2013). Influence of taro (Colocasia esculenta L Schott). growth conditions on the phenolic composition and biological properties. Food Chemistry, 141 (4), 3480-3485.

https://doi.org/10.1016/j.foodchem.2013.06.009

18. Griffith, O.W. (1980). Determination of glutathione and glutathione disulfide using glutathione reductase and 2-vinylpyridine. Analytical Biochemistry, 106(1), 207-212.

https://doi.org/10.1016/0003-2697(80)90139-6

19. Habig, W.H., Pabst, M.J., Jakoby, W.B. (1974). Glutathione S-transferases: The first enzymatic step in mercapturic acid formation. Journal of Biological Chemistry, 249(22), 7130-7139. https://doi.org/10.1016/S0021-9258(19)42083-8

20. Hansen, M.B., Nielsen, S.E., Berg, K. (1989). Re-examination and further development of a precise and rapid dye method for measuring cell growth/cell kill. Journal of Immunological Methods, $119(2), 203-210$.

https://doi.org/10.1016/0022-1759(89)90397-9

21. Hayes, J.D., Dinkova-Kostova, A.T., McMahon, M. (2009). Cross-talk between transcription factors AhR and Nrf2, lessons for cancer chemoprevention from dioxin. Toxicological Sciences, $111(2), 199-201$.

https://doi.org/10.1093/toxsci/kfp168

22. Hunt, J. (1980). Determination of total sulfur in small amounts of plant material. The Analyst, 105(1246), 83-85.

https://doi.org/10.1039/an9800500083

23. Kaushal, P., Kumar, V., Sharma, H.K. (2015). Utilization of taro (Colocasia esculenta). A review. Journal of Food Science and Technology, 52, 27-40.

https://doi.org/10.1007/s13197-013-0933-y

24. Keyaerts, E., Vijgen, L., Pannecouque, C., Van Damme, E., Peumans, W., Egberink, H., Balzarini, J., Van Ranst, M. (2007). Plant lectins are potent inhibitors of coronaviruses by interfering with two targets in the viral replication cycle. Antiviral Research, 75(3), 179-187.

https://doi.org/10.1016/j.antiviral.2007.03.003

25. Kitchens, R.L. (2000). Role of CD14 in cellular recognition of bacterial lipopolysaccharides. Chemical Immunology, 74, 61-67.

https://doi.org/10.1159/000058750

26. Kundu, N., Campbell, P., Hampton, B., Lin, C.Y., Ma, X., Ambulos, N., Zhao, X.F., Goloubeva, O., Holt, D., Fulton, A.M. (2012). Antimetastatic activity isolated from Colocasia esculenta (taro). Anticancer Drugs, 23(2), 200-211. https://doi.org/10.1097/CAD.0b013e32834b85e8

27. Larsen, B., Haug, A., Painter, J.T.J. (1966). Sulfated polysaccharides in brown algae. I. Iisolation and preliminary characterization of three sulfated polysaccharides from Ascophylum nodosum. Acta Chemica Scandinavica, 20, 219-230.

https://doi.org/10.3891/acta.chem.scand.20-0219

28. Lee, S., Wee, W., Yong, J., Syamsumir, D. (2011). Antimicrobial, antioxidant, anticancer property and chemical composition of different parts (corm, stem and leaves) of Colocasia esculenta extract. Annales Universitatis Mariae Curie-Sklodowska, LublinPolonia, Sectio DDD, Pharmacia, 24(3), 9-16.

29. Li, Y., Seto, E. (2016). HDACs and HDAC inhibitors in cancer, development and therapy. Cold Spring Harbor Perspectives in Medicine, 6(10), art. no. a026831.

https://doi.org/10.1101/cshperspect.a026831

30. Lim, T.K. (2015). Colocasia esculenta in Edible Medicinal and Non-Medicinal Plants. Springer, Germany. Vol. 9, pp. 454- 492. https://doi.org/10.1007/978-94-017-9511-1_13

31. Lowry, O.H., Rosenbrough, N.J., Farr, A.L., Randall, R.J. (1951). Protein measurement with the Folin-phenol reagent. Journal of Biological Chemistry, 193(1), 265-275. https://doi.org/10.1016/S0021-9258(19)52451-6

32. Lund, E. (2011). An exposure driven functional model of carcinogenesis. Medical Hypotheses, 77(2), 195-198. https://doi.org/10.1016/j.mehy.2011.04.009

33. Mähner, C., Lechner, M.D., Nordmeier, E. (2001). Synthesis and characterization of dextran and pullulan sulfate. Carbohydrate Research, 331 (2), 203-208.

https://doi.org/10.1016/s0008-6215(00)00315-3

34. Mescher, M., Haarmann-Stemmann, T. (2018). Modulation of CYP1A1 metabolism, from adverse health effects to chemoprevention and therapeutic options. Pharmacology, Therapeutics, 187, 71-87.

https://doi.org/10.1016/j. pharmthera.2018.02.012 
35. Mollakhalili, M.N., Mortazavian, A.M., Bahadori, M.A., Sohrabvandi, S., Aghaei, M.F. (2017). Phytochemicals in cancer prevention, a review of the evidence. International Journal of Cancer Management, 10(1), art. no. e7219.

https://doi.org/10.17795/ijcp-7219

36. Moorcroft, M., Davis, J., Compton, R.G. (2001). Detection and determination of nitrate and nitrite, a review. Talanta, 54(5), 785-803.

https://doi.org/10.1016/s0039-9140(01)00323-x

37. Noorfarahzilah, M., Lee, J.S., Sharifudin, M., MohdFadzelly, A., Hasmadi, M. (2014). Applications of composite flour in development of food products. International Food Research Journal, 21(6), 2061- 2074.

38. Nwauzoma, A., Dappa, M.S. (2013). Ethnobotanical studies of Port Harcourt Metropolis, Nigeria. ISRN Botany, 2013, art. no. 829424 .

https://doi.org/10.1155/2013/829424

39. Park, H.R., Lee, H.S., Cho, S.Y., Kim, Y.S., Shin, K.S. (2013). Antimetastatic effect of polysaccharide isolated from Colocasia esculenta is exerted through immunostimulation. International Journal of Molecular Medicine, 31 (2), 361-368. https://doi.org/10.3892/ijmm.2012.1224

40. Partridge, S.M. (1949). Aniline hydrogen phthalate as spraying reagent for chromatography of sugars. Nature, 164, 443-446. https://doi.org/10.1038/164443a0

41. Pereira, P.R., Corrêa, A., Vericimo, M.A., Paschoalin, V. (2018). Tarin, a potential immunomodulator and COX-inhibitor lectin found in taro (Colocasia esculenta). Comprehensive Reviews in Food Science and Food Safety, 17(4), 878-891.

https://doi.org/10.1111/1541-4337.12358

42. Prabhu, V., Guruvayoorappan, C. (2010). Nitric oxide, pros and cons in tumor progression. Immunopharmacology and Immunotoxicology, 32(3), 387-392.

https://doi.org/10.3109/08923970903440192
43. Reyad-ul-Ferdous, M., Arman, M.S.I., Tanvir, M.M.I., Sumi, S., Siddique, K.M.M.R., Billah, M.M., Islam, S. (2015). Biologically potential for pharmacologicals and phytochemicals of medicinal plants of Colocasia esculenta, A comprehensive review. American Journal of Clinical and Experimental Medicine, 3(5-1), 7-11. https://doi.org/10.11648/j.ajcem.s.2015030501.12

44. Sakano, Y., Mutsuga, M., Tanaka, R., Suganuma, H., Inakuma, T., Toyoda, M. (2005). Inhibition of human lanosterol synthase by the constituents of Colocasia esculenta (taro). Biological and Pharmaceutical Bulletin, 28(2), 299- 304.

https://doi.org/10.1248/BPB.28.299

45. Sun, S.Y., Hail, N. J.R., Lotan, R. (2004). Apoptosis as a novel target for cancer chemoprevention. Journal of the National Cancer Institute, 96(5), 662-672.

https://doi.org/10.1093/jnci/djh123

46. Tan, A.C., Konczak, I., Sze, D.M., Ramzan, I. (2011). Molecular pathways for cancer chemoprevention by dietary phytochemicals. Nutrition and Cancer, 63(4), 495-505.

https://doi.org/10.1080/01635581.2011.538953

47. Tanaka, T., Ishigamori, R. (2011). Understanding carcinogenesis for fighting oral cancer. Journal of Oncology, 2011, art. no. 603740. https://doi.org/10.1155/2011/603740

48. Temesgen, M., Retta, N. (2015). Nutritional potential, health and food security benefits of taro Colocasia esculenta (L)., A review. Food Science and Quality Management, 36, 23-30.

49. Xu, X., Lai, Y., Hua, Z.-C. (2019). Apoptosis and apoptotic body, disease message and therapeutic target potentials. Bioscience Reports, 39(1), art. no. BSR20180992.

https://doi.org/10.1042/BSR20180992

50. Yang, J., Du, Y., Wen, Y., Li, T., Hu, L. (2003). Sulfation of Chinese lacquer polysaccharides in different solvents. Carbohydrate Polymers, 52(4), 397-403. https://doi.org/10.1016/S0144-8617(02)00330-2 
